\title{
СТРУКТУРНИЙ СИСТЕМНИЙ АНАЛІЗ ГНУЧКИХ ВИРОБНИЧИХ СИСТЕМ
}

\begin{abstract}
Вступ
В умовах ринкової економіки, коли необхідно оперативно та адекватно реагувати на поступаючі замовлення, сучасне виробництво повинно мати кількісну та якісну гнучкість. Це означає, що виробництво повинно мати здатність швидко та в широких межах змінювати об'єми та асортимент продукції що випускається.

Можливість зміни асортименту продукції що випускається досягається за рахунок використання гнучких виробничих систем (ГВС).

Дослідження сучасних ГВС це перш за все їх опис. Але опис-це по суті їх моделювання, яке як інструмент дослідження та побудови системи дуже важливе з урахуванням вимог до формалізації останньої. Це пояснюється такою перевагою моделі перед словесним описом, як стислість та точність представлення, що робить зрозумілою загальну структуру ГВС та розкриває причинно-наслідкові зв'язки між їі елементами.

Особливості дослідження ГВС визначають форму опису моделі. В більшості випадків використовуеться символьна форма. Вона завжди абстрактна і тому забезпечує можливість формального з нею поводження та використання.
\end{abstract}

\section{Постановка задачі}

Серед властивостей ГВС, які досліджуються, найважливішими будемо вважати функціональні властивості. Дискретність ГВС дає можливість оперувати в ході опису представленнями та термінами теорії множин. Тому, виділивши у складі ГВС окремий елемент і розглянувши його як одинарну множину, яка протипоставляється підсистемам ГВС як другій самостійній множині, можна по структурі зв'язків встановити їх взаємопов'язаність. Зв'язані елементи можна вважати поставленими у відповідність. Тоді є можливість визначити, які елементи другої множини поставлені у відповідність до першої одинарної множини, тобто як на першу множину відображена друга. Таке відображення однієї множини на іншу має назву функція. Отже, можна розглядати вузол зв“язку структури зв'язності, який відповідає входженню будь-якого елемента ГВС в сітку зв“язків відповідної підсистеми як функцію цього елемента в підсистемі та означений тип відношень з іншими їі елементами. Тому для виявлення функціональних властивостей елементів необхідно встановити в ході дослідження ГВС структурні зв'язки між їі підсистемами. В той же час, знання функцій окремих елементів ще не дає повної інформації про систему. Тільки комплексне дослідження ГВС здатне забезпечити виявлення всіх характеристик як окремого елемента, так i

${ }^{0}$ (C) M.М. Ткач, 2006 
системи в цілому, що вимагає розгляду двох аспектів даної проблеми: структурно-функціонального та морфологічного аналізу ГВС.

\section{Структурно-функціональний аналіз ГВС}

Якщо розглянути ГВС як “чорну скриньку” (рис. 1), то на вході маємо заготівки, технологічні процеси та план, а на виході - готові вироби. Але ГВС ще має відповідне забезпечення: інструмент, технологічне оснащення, мастила, охолоджуюча рідина і т. д., а також необхідність прибирання відходів. Все це теж рухається і утворює всередині ГВС свої потоки. Крім того, таке оснащення як супутники, магазини, палети, які теж рухаються, але не виходять за межі системи, утворять ще один додатковий матеріальний потік.

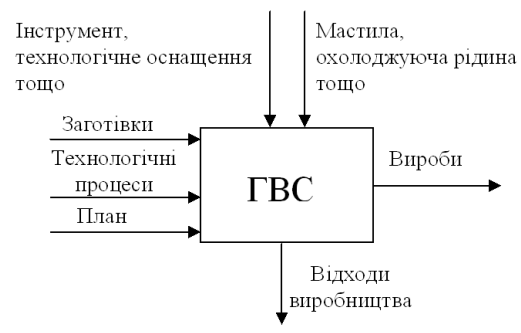

Рис. 1 - Основні вхідні та вихідні матеріальні потоки ГВС

Таким чином, можна відмітити наступні основні матеріальні потоки, які протікають через ГВС: предметний, інструментальний та потік відходів.

Предметний потік визначає головну мету ГВС - перетворення заготівок в готові вироби. Для цього заготовки, які введені до ГВС зовнішнім для неї транспортом, потрапляють до пунктів комплектації. Після встановлення їх на відповідне оснащення (спутник, палета і т.д.) вони переміщуються на склад заготовок, де і чекають призначення на обробку. Після призначення обробки заготовки переміщуються до першого за технологічним маршрутом ГВМ і знов накопичуються в його зоні. Після обробки на першому ГВМ напівфабрикат переміщується знов на склад і там чекає призначення на наступну операцію. I так повторюється стільки разів, скільки визначено технологічним маршрутом виготовлення виробу. Після останньої технологічної операції виріб проходить контроль і переміщується на склад готової продукції.

Інструментальний потік подібен до предментного, але має деякі відмінності. Так інструмент, на відміну від заготовки, не оброблюеться, а зношується. На виході з ГВС він не виріб, а відпрацьований інструмент, який іде у відходи або поновлюеться. Частина інструменту, який не потребує поновлення, повертається у систему для подальшого використанHя. 
Цілком природньо, що такі процедури здійснюються і з технологічним оснащенням.

Потік відходів виробництва значно простіший. Відходи, які накопичуються біля кожного ГВМ в спеціальній тарі після ії наповнення виводяться з системи.

Отже, для реалізації виробничого процесу, ГВС, поряд з підсистемами перетворення заготівок в готові вироби, повинна мати ще й підсистеми, які забезпечують реалізацію, контроль та координацію потоків заготовок, деталей, оснащення та інструменту.

Тоді ГВС можна розглядати як організовану множину взаємопов'язаних між собою елементів, які виконують означені функції для досягнення загальної мети, а при їі аналізі опиратися на один з методів системних досліджень, а саме - структурно-функціональний аналіз. Останній вивчає об'єкти та процеси з точки зору функцій, які вони виконують по відношенню до більш складних систем, до складу яких вони входять [ 1 ] .

Розглянемо ГВС як сукупність функцій, які вона виконуе. Загальна фуннкція полягае в перетворенні множини заготовок $Z=\left\{z_{k}\right\}, k \in[1, K]$ в можину готових виробів $V=\left\{v_{l}\right\}, l=[1, L]$ :

$$
F_{\Gamma B C}: Z \rightarrow V \text {. }
$$

Однак, встановлення інтегральної функції ГВС не вичерпуе усіеї повноти її дослідження, бо ця функція забезпечуеться функціями окремих елементів системи. Тому дослідження передбачае диференціацію цієї функції на всю глибину побудови ГВС.

У відповідності до розбиття загального виробничого процесу на окремі операції, загальна фуннкція $F_{\Gamma B C}$ розчленовуеться на сукупність функцій окремих операцій:

$$
F_{\Gamma B C} \rightarrow\left\{F_{T}, F_{T P}, F_{C}, F_{I 3}, F_{K}, F_{B B}, F_{y}\right\},
$$

де $F_{T}$ - функція технологічного перетворення об'єктів; $F_{T P}$ - функція транспортування; $F_{C}$ - фрункція складування; $F_{I 3}$ - функція інструментального забезпечення; $F_{K}$ - функція контролю; $F_{B B}$ - функція видалення відходів; $F_{y}-$ фуннцція управління.

Кожна з виділених функцій $\left\{F_{T}, F_{T P}, F_{C}, F_{I 3}, F_{K}, F_{B B}, F_{y}\right\}$ реалізуеться відповідною функціональною підсистемою $G_{i}$ :

$F_{T} \rightarrow G_{T} ; F_{T P} \rightarrow G_{T P} ; F_{C} \rightarrow G_{C} ; F_{I 3} \rightarrow G_{I 3} ; F_{K} \rightarrow G_{K} ; F_{B B} \rightarrow G_{B B} ; F_{y} \rightarrow G_{y} \quad$, де $G_{T}$ - технологічна підсистема; $G_{T P}$ - транспортна підсистема; $G_{C}$ - підсистема складування; $G_{I 3}$ - підсистема інструментального забезпечення; $G_{K}$ - підсистема контролю; $G_{B B}$ - підсистема видалення відходів; $G y-$ підсистема управління.

Технологічна підсистема $G_{T}$ виконує основну функцію ГВС - перетворення множини заготовок (комплектуючих) $Z$ в множину готових виробів $V$ в автоматичному режимі, що забезпечуеться, крім використання технологічних агрегатів (які виконують основні технологічні операції по заданій програмі) також наявністю і узгодженою роботою допоміжних 
елементів, які входять до складу $G_{T}$. Технологічні агрегати та допоміжні елементи об'єднуються в технологічні модулі, які мають назву - гнучкі виробничі модулі (ГВМ) і забезпечують виконання групи взаємозв'язаних технологічних операцій.

Таким чином, обробне (складальне) обладнання, що включається в $G_{T}$, має забезпечити максимальну концентрацію операцій та їх сумісництво для обробки (складання) при одноразовому встановленні виробу. Цим завданням у найбільшій мірі відповідають сучасні багатоопераційні верстати - обробні (складальні) центри ОЦ (СЦ) з числовим програмним управлінням (ЧПУ).

Транспортна підсистема $G_{T P}$ об‘еднуе транспортними зв‘язками підсистеми ГВС в едину систему, виконуе в ході технологічного процесу доставку заготовок, інструменту, оснащення тощо на палетах і в тарі, дає змогу вирівнювати предметні потоки завдяки проміжному нагромадженню заготівок, напівфабрикатів тощо з їх гнучким адресуванням шляхом зміни послідовності обходу ГВМ, що забезпечуе оптимальне завантаження $G_{T}$. Підсистема $G_{T P}$ конструктивно компонуеться на основі різноманітних рухомих транспортних засобів: конвейерів (самопливні, вібраційні, ролікові тощо); автономних транспортних модулів (ATM) з оптичними, електромагнітними та ультразвуковими системами навігації; прийомо-передаючих пристроїв.

Підсистема складування $G_{C}$ відповідно до змінно-добового графріка роботи $Г В С$ в единому ритмі з $G_{T}$ виконуе прийом, складування, переставляння, зберігання, комплектацію, завантаження-вивантаження на вході-виході ГВС потоку заготовок, напівфабрикатів, інструменту, технологічного оснащення тощо. В більшості ГВС підсистеми $G_{C}$ для заготовок, інструменту, готової та проміжної продукції відокремлені. Однак, в умовах невеликого за обєемом виробництва та в залежності від специфічних умов вони можуть об‘єднуватись. В централізованих $G_{C}$ краще використовуються складські емності, але зростають транспортні витрати. Децентралізовані $G_{C}$ дозволяють зменшити ці витрати за рахунок безпосередньої передачі заготовок, напівфабрикатів тощо з одного ГВМ на інший, але використання складських емностей при цьому знижуеться. Тому, як правило, використовується дворівнева структура -центральний склад та проміжні накопичувачі. Співвідношення об'емів центральних та проміжних складів залежить від специфічних умов виробництва.

Підсистема інструментального забезпечення $G_{I 3}$ здійснюе підготовку, нагромадження, доставку, повернення, діагностування та інші операції, які пов'язані з забезпеченням ГВС інструментом в умовах діючого технологічного процесу. Оскільки інструмент повинен десь зберігатись, то до складу $G_{I 3}$ входить автоматизований інструментальний склад, в якому і розміщуються магазини з інструментом. Доставка інструментальних магазинів до технологічного обладнання ГВМ здійснюеться або загальною, або спеціальною $G_{T P}$. Доставлені магазини встановлюються в означеній позиції біля технологічного обладнання ГВМ, а відповідні елементи $G_{I 3}$ здійснюють необхідні зміни в його інструментальному магазині. 
Інколи інструментальні магазини технологічного обладнання виконуються з`емними. В цьому випадку вони виконують функцію і збереження i транспортування інструменту. Зазвичай технологічне обладнання ГВМ комплектуеться інструментом в розрахунку на декілька типів виробів. В цьому випадку $G_{I 3}$ включае, крім центрального інструментального складу та інструментальних магазинів технологічного обладнання ГВМ, ще і групові інструментальні склади. Така система підвищуе гнучкість, скорочуе час пошуку та транспортування необхідного інструменту.

Підсистема контролю $G_{K}$ здійснюе вихідний, міжопераційний та остаточний контроль параметрів заготовок, напівфрабрикатів, виробів, інструменту тощо, визначає і контролюе моменти зміни інструменту за статистичними нормативами або за його фрактичним станом, а також контролюе видалення відходів з зони ГВМ. Підсистема $G_{K}$ базуеться на основі програмованих контрольно-вимірювальних модулів з використанням вимірювальних пристроїв різного призначення, зокрема, контрольних пристроїв, які мають вихід на ЕОМ для обробки та передачі результатів вимірювання. Особливо ефективні ті контрольні пристрої, які забезпечують корекцію параметрів обробки (складдання).

Необхідно відмітити, що процес контролю, з одного боку, пов'язаний з використанням спеціального обладнання, транспортних засобів і промислових роботів, а з іншого - з необхідністю контролю положення елементів цього обладнання. Отже, підсистема $G_{K}$ повинна ще забезпечувати підтримку на відповідному рівні параметрів та положень елементів технологічного, контрольного та транспортного обладнання.

Підсистема видалення відходів $G_{B B}$ видаляе відходи від $G_{T}$ і доставляе їх у зону сортування, переробки, пакування та утилізації. Реалізуеться вона за допомогою спеціальної автоматизованої транспортної системи видалення відходів. Відходи з робочої зони ГВМ потрапляють в тару напряму або за допомогою індивідуального конвейера. Заповнена тара переміщуеться на позицію видачі, а на їі місце встановлюеться нова. 3 позиції видачі заповнена тара забирається загальним транспортним засобом і відвозиться до місця прийому.

Підсистема управління $G y$ здійснюе управління та взаємозв'язок між всіма підсистемами ГВС, збір та розподілення інформації про наявність заготовок, напівфабрикатів тощо, ступінь укомплектованності ГВС інструментом та оснащенням, а також інші операції, які пов'язані з організацією виробництва. Підсистема $G$ п представляе собою комплексну багатофункціональну ієрархічно побудовану систему, яка включає організаційно-технологічну систему управління та систему управління технологічними процесами. Основною метою організаційно-технологічної системи управління є організаційне забезпечення функціонування всіх підсистем ГВС як единого цілого та синхронізація всіеї підготовки та оперативного управління виробництвом в організаційному плані. Система управління технологічними процесами виробляе та реалізуе управляючі впливи на комплекси основного та допоміжного обладнання підсистем ГВС. Вона повинна забезпечити управління технологічними процесами 
та функціональними підсистемами ГВС в реальному маштабі часу.

Таким чином, ГВС може бути представлена як множина, яка включає в себе означені вище функціональні підсистеми:

$$
G V S=\left\{G_{i}\right\}, i \in I=\{T, T P, C, I 3, K, B B, Y\} .
$$

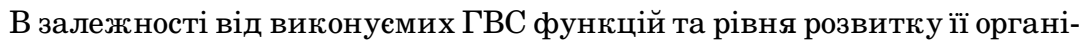
заційної структури, остання може містити різні комбінації підсистем $G_{i}$. Так, в загальному вигляді ГВС може бути представлена системою, яка включае всі означені вище підсистеми:

$$
G V S=\prec G_{T}, G_{T P}, G_{C}, G_{I 3}, G_{K}, G_{B B}, G_{y} \succ .
$$

Прикладом такої системи може бути ГВС обробки, структура якої наведена на рис. 2.

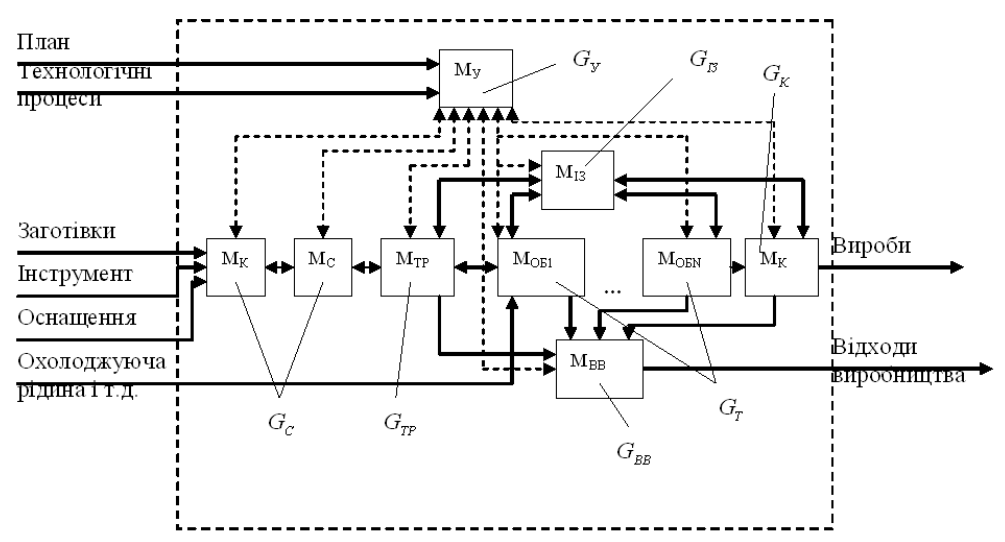

Рис. 2 - Структура ГВС обробки: $M_{\kappa}$ - модуль комплектації; $M_{C}$ - модуль складування; $M_{T P}$ - модуль транспортуваня; $M_{O Б 1} \ldots M_{O L N}-$ модулі обробки; $M_{K}$ - модуль контролю; $M_{I 3}$ - модуль інструментального забезпечення; $M_{B B}$ - модуль видалення відходів; $M y$ - модуль управління.

В совою чергу, кожна з виділених підсистем $G_{i}$ може розглядатись як відносно відокремлена частина, яка зв'язана з іншими підсистемами та складається з організованої множини взаємозалежних між собою елементів, які виконують означені функції для досягненя загальної мети. Виходячи з цього, виділені підсистеми можуть бути розбиті на більш дрібні підсистеми. Так, наприклад, підсистема $G_{T}$, загальна фрункція якої полягає в здійснені відповідних операцій перетворення (обробки, складання тощо), може бути розбита на ряд підсистем $g_{T_{j}}$, а у відповідності до декомпозиції функції $F_{T}$ - на ряд підфункцій:

$$
F_{T} \rightarrow\left\{f_{\Pi}, f_{3 P}, f_{T H}, f_{K}, f_{y}\right\},
$$

кожна з виділених функцій реалізуеться відповідною підсистемою $g_{T_{j}}$ :

$$
f_{\Pi I} \rightarrow g_{T_{\Pi}} ; f_{3 P} \rightarrow g_{T_{3 P}} ; f_{T H} \rightarrow g_{T_{T H}} ; f_{K} \rightarrow g_{T_{K}} ; f_{y} \rightarrow g_{T_{Y}},
$$


де $g_{T_{\Pi}}$ - підсистема перетворення заготовок, напівфабрикатів тощо. Здійснюе безпосередне виконаня операцій перетворення, в ході виконання

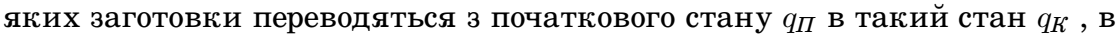
якому вони здатні виконувати визначені для них конструктором функції, тобто в готовий виріб. В якості засобів перетворення використовуються ОЦ (СЦ);

$g_{T_{3 P}}$ - підсистема завантаження-розвантаження. Забезпечує передачу заготовок, напівфабрикатів тощо з внутрішньомодульних транспортних засобів в робочу зону технологічного обладнання і навпаки, а також на інші транспортні засоби. До складу підсистеми входять засоби “човникової" дії, поворотні засоби та промислові роботи;

$g_{T_{T H}}$ - транспортно-накопичувальна підсистема. Ця підсистема здійснюе внутрішньомодульне транспортування заготовок, напівфабрикатів, інструменту тощо. До складу підсистеми входять різні моделі технологічного транспорту;

$g_{T_{K}}$ - підсистема контролю. Забезпечуе одержання заданих показників якості продукції. Вона включає засоби контролю наявності заготовок, напівфабрикатів тощо в робочій зоні технологічного обладнання та правильність виконання відповідних технологічних операцій;

$g_{T_{y}}-$ підсистема управління. Здійснюе управління і взаємозв'язок між всіма підсистемами $g_{T_{j}}$, а також збір та передачу інформації про наявність та ступінь укомплектованості модуля технологічним оснащенням та інструментом до підсистеми управління більш високого рівня.

Тоді підсистема $G_{T}$ може бути представлена наступним чином:

$$
G_{T}=\left\{g_{T_{j}}\right\}, j \in J=\{\Pi, 3 P, T H, K, Y\} .
$$

Аналогічним чином може бути проведена декомпозиція і інших підсистем $G_{i}$.

Кожна з виділених підсистем $g_{T_{j}}$ реалізуеться відповідними технічними засобами $\left\{t z_{T_{j_{k}}}\right\}, T \in I, j \in J, k \in[1, K]$, формалізація вибору яких грунтуеться на використанні методу типових рішень [2].

Виявлені в результаті структурно-функціонального аналізу функціональні властивості елементів ГВС ще не дають повної інформації про систему, оскільки, крім функціональних властивостей, елементам ГВС притаманні ще й зв'язки. А враховуючи багатогранність цих зв'язків, необхідно виявити ще й структури, в залежності від того, про зв'язки якого типу йде мова.

\section{Морфологічний аналіз ГВС}

Морфологічний аналіз складаеться з різностороннього розгляду ГВС та опису її в деякому просторі ознак. В нашому випадку морфологічний аналіз ГВС, який визначае склад їі елементів, множину зв'язків між ними та структуру їі організації, покликаний конкретизувати загальний вираз:

$$
S=\{E, R, C\},
$$


де $S$ - символ означення системи; $E$ - множина елементів системи та їх властивостей; $R$ - множина зв'язків; $C$ - структура організації системи.

Множина елементів ГВС $E$ визначаеться множиною технічних засобів $T Z=\left\{t z_{i}\right\}$, які реалізують відповідні функціональні підсистеми $G_{i}$. При цьому кожен елемент виявляється через значення його властивостей, які можуть бути якісними або числовими. Якісні властивості, які ще називають ознаками, характеризують лише міркування типу “такні”, тобто елемент або має дану ознаку, або ні. Числові властивості, які ще називають параметрами, визначають інтервали значень для кожної властивості.

Множина $R$ зв'язків між елементами ГВС за своїм призначенням поділяється на матеріальні $r_{M}$ та інформаційні $r_{H}$, а за своїм характером на прямі $r_{\Pi}$ та зворотні $r_{3}$. Тобто $R=\left\{r_{M}, r_{H}, r_{\Pi}, r_{3}\right\}$.

Структура організації ГВС $C$, в залежності від характеру відносин між їі елементами, може бути технологічною, функціональною та організаційною.

Технологічна структура $C_{T}$ - кінцева множина упорядкованих сукупностей ГВМ, які ідентифікують технологічні процеси виготовлення виробів, тобто технологічна структура визначае комплекс ГВМ, який забезпечуе реалізацію технологічних процесів, а також схему зв'язків, які з'еднують ГВМ та визначають шляхи руху заготовок, напівфабрикатів тощо при виготовленні.

Функціональна структура $C_{\Phi}$ - сукупність взаємозалежних за допомогою транспортної системи ГВМ, яка реалізуе технологічні процеси виготовлення заданої номенклатури виробів. Вибір функціональної структури пов'язаний з перебиранням великої кількості можливих варіантів технологічного обладнання, його розміщення, варіантів транспортних засобів тощо.

Організаційна структура $C_{O}$ - множина синхронізованих в часі технологічних процесів виготовлення виробів, які задовольняють задані обмеження на тривалість випуску кожного виробу заданої номенклатури.

Таким чином, структура організації ГВС може бути представлена як $C=\left\{c_{T}, c_{\Phi}, c_{O}\right\}$, а їі іерархія:

$$
c_{T} \rightarrow c_{\Phi} \rightarrow c_{O} .
$$

Тоді морфологічний опис ГВС можна представити наступним чином:

$$
G V S=\left\{\left\{t z_{i j_{k}}\right\},\left\{r_{l}\right\},\left\{c_{m}\right\}\right\},
$$

де $\left\{t z_{i j_{k}}\right\}, k \in[1, K]$ - множина технічних засобів, які реалізують всі функціональні підсистеми ГВС;

$\left\{r_{l}\right\}, l \in L=\{M, I, P, O\}$-множина зв'язків між технічними засобами ГВС;

$\left\{c_{m}\right\}, m \in M=\{T, \Phi, O\}-$ множина структур реалізації ГВС.

\section{Висновки}

Проведений функціональний та морфологічний аналіз ГВС дає можливість, використовуючи операції синтезу $Q$, отримати множину рі- 
шень $T$, які задовольняють вихідному завданню $P$ :

$$
Q:(P) \rightarrow T .
$$

При цьому $Q=\left(q_{1}, q_{2}, q_{3}, q_{4}\right)$ включає наступні етапи:

$q_{1}$ - пошук технічних засобів $\left\{t z_{i_{j_{k}}}\right\}, k \in[1, K]$, які реалізують виділені підсистеми $g_{i_{j}}$;

$q_{2}$ - синтез підсистем $g_{i_{j}}$ на основі технічних засобів, які були отримані на попередньому етапі;

$q_{3}$ - синтез функціональних підсистем $G_{i}$ на основі отриманих підсистем $g_{i_{j}}$;

$q_{4}$ - синтез ГВС з підсистем $G_{i}$.

Очевидно, що запропонований підхід до синтезу ГВС дозволяе отримувати декілька варіантів рішень з тим, щоб на етапі моделювання вибрати найбільш раціональний варіант.

\section{Література}

1. Тимченко А.А., Родионов А.А. Основы информатики системного проектирования объектов новой техники. К.: Наук. думка, 1991.- 152 с.

2. Коробецький Ю.П., Рамазанов С.К. Імітаційні моделі в гнучкому виробництві.- Луганськ.: Вид-во СНУ ім. В. Даля, 2003.- 280 с. 